\title{
Snemmkominn árangur opinna ósæðarlokuskipta við ósæðarloku- prengslum hjá konum á Íslandi
}

\author{
Anna Guðlaug Gunnarsdóttir ${ }^{1}$ \\ Kristján Orri Víđisson ${ }^{1}$ \\ Sindri Aron Viktorsson ${ }^{2}$ \\ Árni Johnsen ${ }^{1}$ \\ Daði Helgason ${ }^{3}$ \\ Inga Lára Ingvarsdóttir ${ }^{4}$ \\ Sólveig Helgadóttir ${ }^{5}$ \\ Arnar Geirsson ${ }^{6}$ \\ Tómas Guðbjartsson ${ }^{1,2}$
}

Höfundar eru öll læknar.

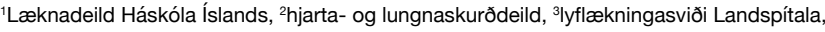
${ }^{4}$ svæfinga- og gjörgæsludeildum Sahlgrenska háskólasjúkrahússins í Gautaborg, ${ }^{5}$ og Akademíska háskólasjúkrahússins í Uppsölum, ${ }^{6}$ hjartaskurđdeild Yale-háskólasjúkrahússins, New Haven.

Fyrirspurnum svarar Tómas Guððbjartsson, tomasgudbjartsson@hotmail.com

\section{Inngangur}

Ósæðarlokuprengsli (aortic stenosis) er algengasti lokusjúkdómurinn í fullorðnum á Vesturlöndum. ${ }^{1}$ Algengi sjúkdómsins eykst með hækkandi aldri og hrjáir um 2,8\% einstaklinga á aldrinum 60-74 ára en um $13 \%$ einstaklinga eldri en 75 ára. ${ }^{2}$ Aldursbundin kölkun á eðlilegri príblöðkuloku er algengasta orsök ósæðarlokuprengsla í fullorðnum og greinist yfirleitt upp úr sextugu en einstaklingar með meðfædda tvíblöðkuloku (um 1-2\% algengi) greinast fyrr á ævinni..$^{1,3}$

Meingerð ósæðarlokuprengsla er margpætt og flókin en lokublöðin pykkna og stífna vegna kölkunar. Pannig prengist ósæðarlokan og til að viðhalda útstreymishlutfalli hjartans pykknar vinstri slegillinn, sem aftur eykur á súrefnispörf vöðvans. ${ }^{4-6} \mathrm{Al}-$ gengustu einkenni ósæðarlokuprengsla eru mæði, hjartaöng og yfirlið en auk pess geta hjartsláttartruflanir komið fyrir og jafnvel valdið skyndidauða. ${ }^{6,7}$ Lyfjameðferð hefur lítil áhrif á gang sjúkdómsins ${ }^{8}$ og pegar einkenna hjartabilunar verður vart versna lífslíkur einstaklinga hratt. ${ }^{4}$ Hefðbundin meðferð er opin hjartaaðgerð par sem lokunni er skipt út; ýmist fyrir ólífræna loku úr hertu kolefni eða lífræna loku úr svíni eða gollurshúsi kálfs. ${ }^{9}$ Hér á landi eru ósæðarlokuskipti önnur algengasta opna hjartaaðgerðin á eftir kransæðahjáveitu. ${ }^{10}$ Á síðustu árum hefur komið fram ný meðferð við ósæðarlokuprengslum sem kallast ósæðarlokuísetning með præðingartækni, eða TAVI (transcatheter arotic valve implantion), par sem lífrænni loku er komið fyrir í ósæðarlokustað

\begin{abstract}
Á G R I P
Inngangur

Ósæðarlokuskipti er önnur algengasta hjartaskurðaðgerðin á Íslandi. Markmið rannsóknarinnar er að meta i fyrsta sinn á Íslandi snemmkominn árangur opinna ósæðarlokuskipta vegna ósæðarlokuprengsla hjá konum.

\section{Efniviður og aðferðir}

Afturskyggn rannsókn á 428 sjúklingum sem gengust undir opin ósæðarlokuskipti vegna ósæðarlokuprengsla á íslandi 2002-2013. Upplýsingar fengust úr sjúkraskrám og voru skráđir fylgikvillar aðgerðar og farið var yfir hjartaómanir fyrir og eftir aðgerð. Forspárpættir dauða innan 30 daga voru metnir með lógistískri aðhvarfsgreiningu og heildarlifun áætluð (Kaplan-Meier). Miðgildi eftirfylgdartíma var 8,8 ár (0-16,5 ár)
\end{abstract}

\section{Niðurstöður}

Af 428 sjúklingum voru 151 konur $(35,3 \%)$ og voru pær að meðaltali tveimur árum eldri en karlar (72,6 $\pm 9,4$ ára á móti 70,4 $\pm 9,8, p=0,020)$ Einkenni fyrir aðgerð voru sambærileg milli kynja en konur höfðu marktækt hærra EuroSCORE II fyrir aðgerð (5,2 $\pm 8,8$ á móti $3,2 \pm$ 4,6, $p=0,002)$. Hámarks-prýstingsfall yfir ósæðarlokuna var hærra hjá konum $(74,4 \pm 29,3 \mathrm{mmHg}$ á móti $68,0 \pm 23,4 \mathrm{mmHg}, \mathrm{p}=0,013)$ en tíðni snemmkominna fylgikvilla, bæði minniháttar og alvarlegra, var sambærileg milli kynja líkt og 30 daga dánartíðni (8,6\% á móti 4,0\%, $\mathrm{p}=0,076)$ og 5 ára lifun ( $80,1 \%$ á móti $83,0 \%$ fyrir karla, $p=0,49$ ). Kvenkyn reyndist ekki vera forspárpáttur fyrir dauða innan 30 daga pegar leiðrétt var fyrir öðrum pekktum forspárpáttum dauða (ÁH: 1,54, 95\%ÖB: 0,63-3,77) svo sem aldri.

\section{Ályktanir \\ Á Íslandi eru konur um priðjungur peirra sem gangast undir ósæðarlokuskipti vegna ósæðarlokuprengsla. Pær eru rúmlega tveimur árum eldri en karlar pegar kemur að aðgerð og virðast hafa lengra gengin ósæðarlokuprengsli. Tíoni fylgikvilla eftir aðgerð, 30 daga dánartíðni og langtímalifun var engu að sídur sambærileg hjá kynjunum.}

https://doi.org/10.17992//bl.2019.05.230

með præðingartækni. ${ }^{11}$ Nú er pessum ísetningum einkum beitt hjá sjúklingum par sem áhætta við opna aðgerð er talin mikil, til dæmis hjá háöldruðum eða sjúklingum sem áður hafa gengist undir opna hjartaaðgerð. ${ }^{12,13}$ Nýlegar slembirannsóknir á sjúklingum í miðlungs- til lágáhættuhópum hafa hins vegar sýnt svipaðan snemmkominn árangur og við opin ósæðarlokuskipti, en langtíma árangur TAVI-aðgerða er ekki jafn vel pekktur. ${ }^{14-16}$

Erlendis eru konur um 30-50\% peirra sem gangast undir ósæðarlokuskipti ${ }^{17-24}$ og hafa flestar rannsóknir, en pó ekki allar, sýnt ívið hærri 30 daga dánartíðni borið saman við karla. ${ }^{17-24}$ Á Íslandi hafa nokkrar rannsóknir verið gerðar á árangri ósæðarlokuskipta, einkum með áherslu á langtímalifun og fylgikvilla á borð 
Tafla I. Samanburður á sjúklingatengdum páttum fyrir aðgerð. Fjöldi (\%) fyrir flokkabreytur, meðaltal með +/- staðalfráviki fyrir normaldreifðar talnabreytur en miðgildi fyrir ónormaldreifðar talnabreytur.

\begin{tabular}{|c|c|c|c|}
\hline & $\begin{array}{c}\text { Konur } \\
(n=151)\end{array}$ & $\begin{array}{c}\text { Karlar } \\
(\mathrm{n}=277)\end{array}$ & p-gildi \\
\hline Aldur [ár] & $72,6 \pm 9,4$ & $70,4 \pm 9,8$ & 0,020 \\
\hline \multicolumn{4}{|c|}{ Áhættupættir } \\
\hline Líkamspyngdarstuðull [kg/m²] & $27,6 \pm 4,8$ & $27,7 \pm 4,2$ & 0,850 \\
\hline Saga um háprýsting & $113(75,3)$ & $187(67,8)$ & 0,127 \\
\hline Saga um sykursýki & $18(11,9)$ & $45(16,4)$ & 0,268 \\
\hline Saga um blóðfituröskun & $59(39,1)$ & $141(51,6)$ & 0,017 \\
\hline Saga um langvinna lungnateppu & $16(10,6)$ & $18(6,6)$ & 0,205 \\
\hline Fjölskyldusaga um hjarta- og æðasjúkdóma & $52(36,1)$ & $83(31,4)$ & 0,396 \\
\hline Saga um reykingar & $87(58,8)$ & $191(69,7)$ & 0,031 \\
\hline Núverandi reykingar & $22(14,9)$ & $39(14,2)$ & 0,975 \\
\hline Meðfædd tvíblöðkuloka & $33(22,4)$ & $81(30,2)$ & 0,114 \\
\hline \multicolumn{4}{|l|}{ Áætlaður gaukulsíunarhraði } \\
\hline$>60 \mathrm{~mL} / \mathrm{min} . / 1,73 \mathrm{~m}^{2}$ & $72(50,3)$ & $214(79,0)$ & $<0,001$ \\
\hline $30-60 \mathrm{~mL} / \mathrm{min} . / 1,73 \mathrm{~m}^{2}$ & $67(46,9)$ & $52(19,2)$ & $<0,001$ \\
\hline$<30 \mathrm{~mL} / \mathrm{min} . / 1,73 \mathrm{~m}^{2}$ & $4(2,8)$ & $5(1,8)$ & 0,780 \\
\hline Euroscore II (meðaltal \pm staðalfrávik) & $5,19 \pm 8,82$ & $3,21 \pm 4,60$ & 0,002 \\
\hline (miðgildi (bil)) & $2,43(0,67-80,58)$ & $\begin{array}{c}2,03(0,50- \\
48,87)\end{array}$ & 0,001 \\
\hline
\end{tabular}

\begin{tabular}{|c|c|c|c|}
\hline \multicolumn{4}{|c|}{ Fyrri saga um hjartasjúkdóma } \\
\hline Hjartaáfall & $14(9,3)$ & $41(14,9)$ & 0,131 \\
\hline Kransæðavíkkun & $21(13,9)$ & $55(19,9)$ & 0,155 \\
\hline Hjartabilun & $42(27,8)$ & $46(16,7)$ & 0,009 \\
\hline Hjartsláttartruflanir & $40(26,5)$ & $72(26,1)$ & 1,000 \\
\hline \multicolumn{4}{|c|}{ Einkenni fyrir aðgerð } \\
\hline Мæði & $134(88,7)$ & $234(84,5)$ & 0,285 \\
\hline Hjartaöng & $71(47,0)$ & $157(56,7)$ & 0,070 \\
\hline Yfirlið & $26(17,2)$ & $36(13,0)$ & 0,297 \\
\hline Án einkenna & $4(2,6)$ & $9(3,2)$ & 0,959 \\
\hline NYHA-flokkur III eða IV & $96(63,6)$ & $158(57,0)$ & 0,225 \\
\hline CCS-flokkur III eða IV & $40(26,8)$ & $85(31,6)$ & 0,365 \\
\hline \multicolumn{4}{|c|}{ Ómskoðun fyrir aðgerð } \\
\hline Hámarksprýstingsfall yfir ósæðarloku [mmHg] & $74,4 \pm 29,3$ & $68,0 \pm 23,4$ & 0,013 \\
\hline Flatarmál lokuops [cm²] & $0,60(0,28-1,50)$ & $0,70(0,20-2,00)$ & $<0,001$ \\
\hline Flatarmál lokuops/heildar-líkamsyfirborð $\left[\mathrm{cm}^{2} / \mathrm{m}^{2}\right]$ & $0,32(0,15-0,76)$ & $0,34(0,12-0,89)$ & 0,112 \\
\hline Pvermál ósæðarrótar [cm] & $3,1 \pm 0,5$ & $3,5 \pm 0,5$ & $<0,001$ \\
\hline Útfallsbrot vinstri slegils [\%] & $60(20-75)$ & $60(10-77)$ & 0,185 \\
\hline Útfallsbrot vinstri slegils $<35 \%$ & $4(2,7)$ & $10(3,7)$ & 0,814 \\
\hline Pykkt á bakvegg vinstra slegils [cm] & $1,25 \pm 0,25$ & $1,30 \pm 0,25$ & 0,183 \\
\hline Pykkt sleglaskiptar [cm] & $1,38 \pm 0,31$ & $1,43 \pm 0,29$ & 0,289 \\
\hline Vídd vinstri slegils í panbili [cm] & $4,54 \pm 0,56$ & $5,21 \pm 0,81$ & $<0,001$ \\
\hline Leki við ósæðarloku & $19(18,3)$ & $44(21,1)$ & 0,668 \\
\hline
\end{tabular}

við bráðan nýrnaskaða. ${ }^{25-27}$ Afdrif kvenna hafa hins vegar ekki verið rannsökuð sérstaklega og er markmið pessarar rannsóknar að bæta úr pví með áherslu á snemmkomna fylgikvilla og 30 daga dánartíðni.

\section{Efniviôur og aðferdir}

Rannsóknin var afturskyggn og náði til allra peirra sjúklinga sem gengust undir opin ósæðarlokuskipti vegna ósæðarlokuprengsla á Íslandi frá 1. janúar 2002 til 31. desember 2013. Listi yfir sjúklinga var fenginn úr tveimur aðskildum skrám, annars vegar úr sjúklingabókhaldi Landspítala par sem leitað var að aðgerðarnúmerum fyrir ósæðarlokuskipti (FMD00 og FMD10) og hins vegar úr gagnagrunni hjarta- og lungnaskurðdeildar Landspítala.

Alls gengust 526 einstaklingar undir ósæðarlokuskipti á tímabilinu. Útilokaður var 51 sjúklingur par sem aðalábending aðgerðar var lokuleki eða hjartapelsbólga, 35 einstaklingar sem áður höfðu gengist undir hjartaaðgerð og 12 sjúklingar par sem gögn vantaði. Eftir voru 428 sjúklingar sem mynduðu rannsóknarpýðið.

Upplýsingar fengust úr sjúkraskrám og aðgerðarlýsingum. Skráðar voru yfir 130 breytur fyrir hvern sjúkling, par á meðal aldur, kyn, einkenni fyrir aðgerð, niðurstöður hjartaómana fyrir og eftir aðgerð, áhættupættir hjarta- og æðasjúkdóma og fylgikvillar eftir aðgerð. Farið var yfir heilsufarssögu sjúklinganna og skráð hvort saga var um hjartaáfall, hjartabilun, sykursýki, háprýsting og/eða blóðfituröskun. Nýrnastarfsemi var metin fyrir hvern sjúkling með Cockcroft-Gault jöfnunni sem gefur áætlaðan gaukulsíunarhraða (GSH, estimated glomerular filtration rate) par sem vægt skert nýrnastarfsemi var skilgreind sem áætlaður GSH $30-60 \mathrm{~mL} / \mathrm{mín} . / 1,73 \mathrm{~m}^{2}$ en verulega skert ef hann var $<30 \mathrm{~mL} / \mathrm{mín} . / 1,73 \mathrm{~m}^{2}$. Einkenni hjartabilunar voru metin eftir NYHA-staðlinum (New York Heart Association) $)^{28}$ og einkenni hjartaangar eftir CCS-staðlinum (Canadian Cardiovascular Society). ${ }^{29}$ Pá var EuroSCORE II reiknað fyrir alla sjúklinga, en pað metur dánarlíkur innan 30 daga eftir hjartaaðgerð. ${ }^{30}$ Loks var skráð hvort um bráða- eða valaðgerð var að ræða og hvort kransæðasjúkdómur var til staðar.

Upplýsingar úr aðgerð, svo sem aðgerðartími, tími á hjarta- og lungnavél og tangartími, voru skráðar í mínútum. Einnig var skráð tegund og stærð ígræddrar loku og hvort önnur aðgerð var framkvæmd samtímis, til dæmis kransæðahjáveituaðgerð, aðgerð á míturloku eða MAZE-aðgerð við gáttatifi. Úr niðurstöðum 
Tafla II. Samanburður á aðgerðartengdum páttum. Fiöldi (\%) fyrir flokkabreytur, meðaltal með +/- staðalfráviki fyrir normaldreifðar talnabreytur en miðgildi fyrir ónormaldreifðar talnabreytur.

\begin{tabular}{|c|c|c|c|}
\hline & Konur $(n=151)$ & Karlar $(n=277)$ & p-gildi \\
\hline Lokugerð & & & 0,896 \\
\hline Ólífræn & $23(15,2)$ & $47(17,0)$ & \\
\hline Lífræn án grindar & $73(48,3)$ & $132(47,7)$ & \\
\hline Lífræn með grind & $55(36,4)$ & $98(35,4)$ & \\
\hline $\begin{array}{l}\text { Stærð ígræddrar loku } \\
\text { [mm] }\end{array}$ & $23,40 \pm 1,90$ & $25,85 \pm 1,90$ & $<0,001$ \\
\hline \multicolumn{4}{|c|}{ Aðgerðartengdir pættir } \\
\hline Bráðaaðgerð & $16(10,6)$ & $44(15,9)$ & 0,174 \\
\hline Aðgerðartími [mín] & $250(135-1645)$ & 262 (124-770) & 0,318 \\
\hline Vélartími [mín] & $156 \pm 60$ & $157 \pm 46$ & 0,836 \\
\hline Tangartími [mín] & $110 \pm 36$ & $116 \pm 34$ & 0,104 \\
\hline Lægsti hiti $\left[{ }^{\circ} \mathrm{C}\right]$ & $34,8(31,4-36,2)$ & $34,9(31,5-37,1)$ & 0,448 \\
\hline \multicolumn{4}{|c|}{ Samhliða aðgerðir } \\
\hline Kransæðahjáveita & $65(43,0)$ & $176(63,5)$ & $<0,001$ \\
\hline Aðgerð á míturloku & $10(6,6)$ & $10(3,6)$ & 0,241 \\
\hline MAZE-aðgerð & $11(7,3)$ & $23(8,3)$ & 0,853 \\
\hline Önnur aðgerð & $25(16,6)$ & $46(16,6)$ & 1,000 \\
\hline
\end{tabular}

hjartaómskoðana sem gerðar voru fyrir aðgerð og 5-7 dögum eftir aðgerð voru skráðar 11 breytur, par á meðal útfallsbrot vinstri slegils, pykkt og stærð vinstri slegils í panbili í cm og hvort leki var til staðar í eða meðfram ígræddu lokunni. Pá var einnig skráður hámarks- og meðalprýstingsfall yfir lokuna í mmHg og stærð lokuopsins (effective orifice area) í $\mathrm{cm}^{2}$ sem einnig var staðlað eftir líkamsyfirborði sjúklings í $\mathrm{m}^{2}$. Par sem upplýsingar um meðalprýstingsfall vantaði oft í niðurstöður hjartaómskoðana var ekki hægt að birta pær mælingar, hvorki fyrir né eftir aðgerð.

Snemmkomnir fylgikvillar eftir aðgerð voru ýtarlega skráðir. Miðað var við 30 daga frá aðgerðinni og kvillunum skipt í minniháttar og alvarlega fylgikvilla. Minniháttar fylgikvillar voru nýtilkomið gáttatif, afturkræf blóðpurrð í heila, fleiðruvökvi sem parfnaðist aftöppunar, minniháttar sýkingar á borð við yfirborðssýkingar í skurðsári, pvagfærasýking og lungnabólga, og bráður nýrnaskaði sem ekki krafðist nýrnaskilunar. Nýrnaskaði var skilgreindur samkvæmt RIFLE-greiningarskilmerkjum, pað er að minnsta kosti 1,5-föld hækkun á kreatíníngildi par sem miðað var við hæsta kreatíníngildi sjúklings fyrstu 7 daga eftir aðgerðina og pað borið saman við grunngildi fyrir aðgerð. ${ }^{31}$ Alvarlegir fylgikvillar voru alvarlegar sýkingar svo sem miðmætisbólga og hjartapelsbólga, nýrnaskaði sem krafðist nýrnaskilunar, bringubeinslos, óafturkræf blóðpurrð í heila, fjöllíffærabilun og hjartadrep skilgreint sem einangraðar ST-breytingar eða nýtilkomið vinstra greinrof á hjartalínuriti með CK-MB hækkun >70mg/L. Einnig voru enduraðgerðir vegna blæðingar flokkaðar með alvarlegum fylgikvillum. Magn blæðingar í brjóstholskera fyrstu 24 klukkustundirnar eftir aðgerðina var skráo í mL ásamt fjölda eininga af rauðblóðkornapykkni sem gefnar voru í sömu sjúkrahúslegu. Legutími sjúklinga var skráður í heilum dögum, bæði á gjörgæslu og heildarlegutími. Loks var skráður dánardagur pegar við átti.
Sjúklingum var fylgt eftir til 1. september 2018 eða fram аð dánardegi. Miðgildi eftirlitstímans var 8,8 ár (bil 0-16 ár og 6 mánuðir). Samtals tók eftirfylgd til 3337 sjúklingaára.

Breytur voru skráðar í tölvuforritið Excel (Microsoft Corp., Redmond, WA). Tölfræði var unnin í tölfræðiforritinu R, útgáfu 3.4.2 (R Foundation for Statistical Computing, 2017). Flokkabreytur voru bornar saman með kí-kvaðrat prófi eða, ef tilfelli voru fá, Fischer-exact prófi. Talnabreytur voru bornar saman með t-prófi ef pær voru normaldreifðar, annars með Wilcox-prófi. Kynjahlutfall yfir tímabilin var reiknað með lógistískri aðhvarfsgreiningu (logistic regression). Marktækni miðaðist við p-gildi <0,05. Heildarlifun (overall survival) var metin með aðferð Kaplan-Meier og logrank-próf notað til að meta marktækan mun milli kynja. Athugað var hvort kvenkyn væri forspárpáttur dauða innan 30 daga með lógistísku aðhvarfsgreiningarlíkani. Í lokalíkaninu var leiðrétt fyrir pekktum áhættupáttum hjarta- og æðasjúkdóma, svo sem aldri, en einnig EuroSCORE II. Einnig var næmisgreining gerð með flóknara líkani af fjölpátta lógistískri aðhvarfsgreiningu par sem teknar voru pær breytur sem sýndu marktæka fylgni við dauða innan 30 daga í einpátta greiningu, skilgreint sem $p<0,1$, og módelið einfaldað með prepavali (stepwise regression). Breytur par sem gildi vantaði voru hermdar (imputed) með fjölhermun með keðjuðum jöfnum (multiple imputation by chained equations, MICE).

Áður en rannsókn hófst lágu fyrir öll tilskilin leyfi frá vísindasiðanefnd (nr. 10-009-V4), Persónuvernd og framkvæmdastjóra lækninga á Landspítala.

\section{Niðurstöður}

Af 428 sjúklingum voru 151 kona (35,3\%) og 277 karlar (64,7\%) og hélst kynjahlutfallið svipað á rannsóknartímabilinu $(\mathrm{p}=0,166)$. Konur voru marktækt eldri en karlar og var meðalaldur peirra $72,6$ ár borið saman við 70,4 ár fyrir karla ( $\mathrm{p}=0,02)$. Samanburður á áhættupáttum hjarta- og æðasjúkdóma og helstu áhættupáttum ósæðarlokuprengsla fyrir bæði kyn er sýndur í töflu I. Hóparnir voru nokkuð sambærilegir nema hvað konur voru líklegri til að hafa vægt skerta nýrnastarfsemi fyrir aðgerð (46,9\% fyrir konur $19,2 \%$ karla, $\mathrm{p}<0,001)$ og fyrri sögu um hjartabilun $(27,8 \%$ fyrir konur $16,7 \%$ karla, $\mathrm{p}=0,009$ ). Pá voru karlar marktækt líklegri til að hafa sögu um blóðfituröskun (51,6\% á móti 39,1\% kvenna, $\mathrm{p}=0,017)$ og reykingar (69,7\% á móti 58,8\% kvenna, $\mathrm{p}=0,031)$. Líkamspyngdarstuðull (LPS) reyndist sambærilegur milli hópa (27,6 $\pm 4,8 \mathrm{~kg} / \mathrm{m}^{2}$ fyrir konur á móti $27,7 \pm 4,2 \mathrm{~kg} / \mathrm{m}^{2}$ fyrir karla, $\mathrm{p}=0,850$ ) sem og hlutfall sjúklinga með meðfædda tvíblöðkuloku $(22,4 \%$ fyrir konur, 30,2\% fyrir karla, $\mathrm{p}=0,114)$. Mæði var langalgengasta einkenni fyrir aðgerð hjá báðum kynjum (88,7\% fyrir konur, 84,5\% fyrir karla, $\mathrm{p}=0$,285) og hlutfall einstaklinga með alvarlega mæði í NYHA-flokki III eða IV var sambærilegt (63,6\% fyrir konur, 57,0\% karla, $\mathrm{p}=0,225)$. Prettán sjúklingar $(3,0 \%)$ voru einkennalausir fyrir aðgerð og fannst par ekki marktækur munur á kynjum $(2,6 \%$ kvenna, 3,2\% karla, $p=0,959)$. Konur reyndust hins vegar með marktækt hærra EuroSCORE II, eða að meðaltali 5,2 borið saman við 3,2 fyrir karla ( $\mathrm{p}=0,002)$.

Helstu niðurstöður hjartaómskoðana fyrir aðgerð eru sýndar í töflu I. Útfallsbrot vinstri slegils var sambærilegt milli kynja en einnig fjöldi sjúklinga með útfallsbrot undir 35\% (2,7\% kvenna 
Tafla III. Samanburður á fylgikvillum eftir aðgerð og öðrum páttum tengdum legunni eftir aðgerð. Fiöldi (\%) fyrir flokkabreytur, meðaltal með +/- staðalfrávik fyrir normaldreifðar talnabreytur en miðgildi fyrir ónormaldreifðar talnabreytur.

\begin{tabular}{|c|c|c|c|}
\hline & $\begin{array}{l}\text { Konur } \\
(n=151)\end{array}$ & $\begin{array}{l}\text { Karlar } \\
(n=277)\end{array}$ & p-gildi \\
\hline Minniháttar fylgikvillar & $106(72,6)$ & $183(66,5)$ & 0,244 \\
\hline Nýtilkomið gáttatif & $79(63,7)$ & $148(62,2)$ & 0,865 \\
\hline Afturkræf blóðpurrð í heila & $1(0,7)$ & $8(2,9)$ & 0,238 \\
\hline Fleiðruvökvi & $27(17,9)$ & $31(11,2)$ & 0,077 \\
\hline Nýrnaskaði án skilunar & $29(20,3)$ & $37(13,7)$ & 0,107 \\
\hline Yfirborðssýking & $14(9,3)$ & $24(8,7)$ & 0,973 \\
\hline Pvagfærasýking & $24(15,9)$ & $17(6,2)$ & 0,002 \\
\hline Lungnabólga & $11(7,3)$ & $37(13,4)$ & 0,079 \\
\hline Alvarlegir fylgikvillar & $45(29,8)$ & $80(29,1)$ & 0,966 \\
\hline Hjartaáfall & $17(11,3)$ & $36(13,0)$ & 0,713 \\
\hline Miðmætisbólga & $0(0,0)$ & $4(1,5)$ & 0,335 \\
\hline Hjartapelsbólga & $0(0,0)$ & $2(0,7)$ & 0,757 \\
\hline $\begin{array}{l}\text { Nýrnaskaði sem krafðist } \\
\text { skilunar }\end{array}$ & $10(6,6)$ & $8(2,9)$ & 0,116 \\
\hline Heilablóðfall & $2(1,3)$ & $5(1,8)$ & 1,000 \\
\hline Fjöllíffærabilun & $19(12,6)$ & $19(6,9)$ & 0,074 \\
\hline Enduraðgerð <30 daga & $31(20,5)$ & $52(18,8)$ & 0,769 \\
\hline Par af vegna blæðingar & $26(17,2)$ & $36(13,0)$ & 0,304 \\
\hline \multicolumn{4}{|c|}{ Annað } \\
\hline Blæðing fyrsta sólarhring [mL] & $730(90-6240)$ & $\begin{array}{c}848(130- \\
5340)\end{array}$ & 0,017 \\
\hline Gjöf rauðkornapykknis [ein] & $5(0-214)$ & $4(0-46)$ & 0,001 \\
\hline Lega á gjörgæslu [dagar] & $1(0-107)$ & $1(1-80)$ & 0,110 \\
\hline Lega á sjúkrahúsi [dagar] & $13(0-143)$ & $10(1-207)$ & 0,022 \\
\hline 30 daga dánartíðni & $13(8,6)$ & $11(4,0)$ & 0,076 \\
\hline
\end{tabular}

3,7\% karla, p=0,814). Hámarksprýstingsfall yfir ósæðarlokuna fyrir aðgerð var hins vegar hærra hjá konum, eða 74,4 $\pm 29,3 \mathrm{mmHg}$ borið saman við 68,0 $\pm 23,4 \mathrm{mmHg}$ hjá körlum, $\mathrm{p}=0,013$. Lokuop kvenna reyndist einnig minna $\left(0,60(0,28-1,50) \mathrm{cm}^{2}\right.$ á móti $0,70(0,20-2,00)$ $\mathrm{cm}^{2}$ hjá körlum, $\left.\mathrm{p}<0,001\right)$ en munurinn var ekki marktækur eftir að leiðrétt var fyrir líkamsyfirborði $\left(0,32(0,15-0,76) \mathrm{cm}^{2} / \mathrm{m}^{2}\right.$ á móti 0,34 $(0,12-0,89) \mathrm{cm}^{2} / \mathrm{m}^{2}$ hjá körlum, $\left.\mathrm{p}=0,112\right)$.

Samanburður aðgerðartengdra pátta er sýndur í töflu II. Aðgerðar-, vélar- og tangartímar voru ápekkir fyrir karla og konur sem og hlutfall ígræddra ólífrænna og lífrænna lokna. Alls fengu 70 einstaklingar (16,4\%) ígrædda ólífræna loku og 358 (83,6\%) lífræna loku; par af 205 (47,9\%) lífræna loku án grindar og 153 (35,7\%) með grind. Lokur sem græddar voru í konur voru að meðaltali minni en karlalokurnar, eða 23,4 $\pm 1,9 \mathrm{~mm}$ borið saman við 25,9 \pm 1,9 mm (p<0,001). Kransæðahjáveita samhliða ósæðarlokuskiptum var gerð hjá 241 sjúklingi (56,3\%); 43,0\% kvenna og 63,5\% karla $(\mathrm{p}<0,001)$. Ekki reyndist marktækur munur á milli kynja pegar skoðaðar voru aðrar fylgiaðgerðir ósæðarlokuskipta ( $>0,2)$, en míturlokuaðgerð var gerð samhliða hjá 20 einstaklingum $(4,7 \%)$,
Tafla IV. Sjálfstæðir forspárbættir 30 daga dánartíđni, ákvarðaðir með lógistískri aðhvarfsgreiningu.

\begin{tabular}{lccc}
\hline & ÁH & $95 \%$ ÖB & p-gildi \\
\hline Aldur & 1,10 & $1,03-1,19$ & 0,008 \\
\hline Euroscore II & 1,07 & $1,03-1,12$ & 0,002 \\
\hline Kvenkyn & 1,54 & $0,63-3,77$ & 0,338 \\
\hline
\end{tabular}

ÁH = áhættuhlutfall. ÖB = öryggisbil.

MAZE-aðgerð hjá 34 einstaklingum (4,7\%) og annars konar hjartaaðgerð hjá 71 einstaklingi (16,6\%).

Snemmkomnir fylgikvillar eru sýndir í töflu III. Alls fengu 289 sjúklingar einhvern minniháttar fylgikvilla $(67,5 \%)$ og fengu konur marktækt oftar pvagfærasýkingu (15,9\% á móti 6,2\% karla, $\mathrm{p}=0,002)$ en aðrir minniháttar fylgikvillar reyndust sambærilegir milli kynja. Samtals greindust 125 sjúklingar (29,2\%) með einhvern alvarlegan fylgikvilla innan 30 daga frá aðgerð en ekki reyndist marktækur munur milli kynja (29,8\% kvenna á móti 29,1\% karla, $\mathrm{p}=0$,966). Á fyrsta sólarhring eftir aðgerð var blæðing í brjóstholskera minni hjá konum eða $730 \mathrm{~mL}$ (bil 90-6240 mL) borið saman við $848 \mathrm{~mL}$ (bil 130-5340mL) ( $\mathrm{p}=0,017)$. Konur fengu hins vegar fleiri einingar af rauðkornapykkni í legunni (5 á móti fjórum einingum hjá körlum, $\mathrm{p}=0,001)$. Miðgildi heildarlegutíma var 13 dagar fyrir konur en 10 dagar fyrir karla $(\mathrm{p}=0,022)$ (tafla III).

Prjátíu dögum frá aðgerð höfðu 24 einstaklingar látist (5,6\%); 13 konur af 151 (8,6\%) og 11 karlar af 277 (4,0\%). Munurinn reyndist ekki marktækur $(\mathrm{p}=0,076)$.

Í fjölpátta aðhvarfsgreiningu reyndist kvenkyn ekki marktækur forspárpáttur aukinnar 30 daga dánartíðni pegar leiðrétt hafði verið fyrir aldri og EuroSCORE II (tafla IV). Par sem aldur og kyn eru hluti af EuroSCORE II var til næmisgreiningar gert annað áhættulíkan sem innihélt marktækar breytur úr einpátta greiningu aðrar en EuroSCORE II, par með talið kvenkyn. Par reyndist kyn heldur ekki spá fyrir um 30 daga dánartíðni (niðurstöður ekki sýndar).

Langtímalifun karla og kvenna eftir ósæðarlokuskipti er sýnd á mynd 1. Einu ári frá aðgerð var heildarlifun kvenna 89,4\% (95\%ÖB: 84,6-94,5) og 93,9\% (95\%-ÖB: 91,1-96,7) fyrir karla og 5 árum frá aðgerð 80,1\% (95\%-ÖB: 74,0-86,7) meðal kvenna og 83,0\% (95\%-ÖB: 78,7-87,5) meðal karla (log-rank-próf $\mathrm{p}=0,49$ ).

\section{Umræða}

Í pessari afturskyggnu rannsókn var borinn saman snemmkominn árangur 151 konu og 277 karla sem gengust undir opin ósæðarlokuskipti vegna ósæðarlokuprengsla. Í ljós kom að heildartíðni snemmkominna fylgikvilla reyndist sambærileg fyrir bæði kyn og ekki reyndist marktækur munur á 30 daga dánartíðni sem var 5,6\% fyrir hópinn í heild (8,6\% fyrir konur og 4\% fyrir karla). Svipaðri dánartíðni fyrir konur hefur verið lýst í erlendum rannsóknum, og allt að $11 \%,{ }^{17}$ pótt í flestum rannsóknum sé hún nær 3-6\%. ${ }^{18-23}$

Hér á landi eru konur rúmur priðjungur (35,3\%) peirra sem gangast undir lokuskipti vegna ósæðarlokuprengsla. Svipuðu hlutfalli hefur verið lýst erlendis ${ }^{17,18,21,22}$ pótt sumar rannsóknir sýni allt að 40-47\% hlutfall kvenna. ${ }^{19,20,23,24}$ Ástæða lægra hlutfalls kvenna hér á landi er ekki augljós en erlendis hafa rannsóknir 


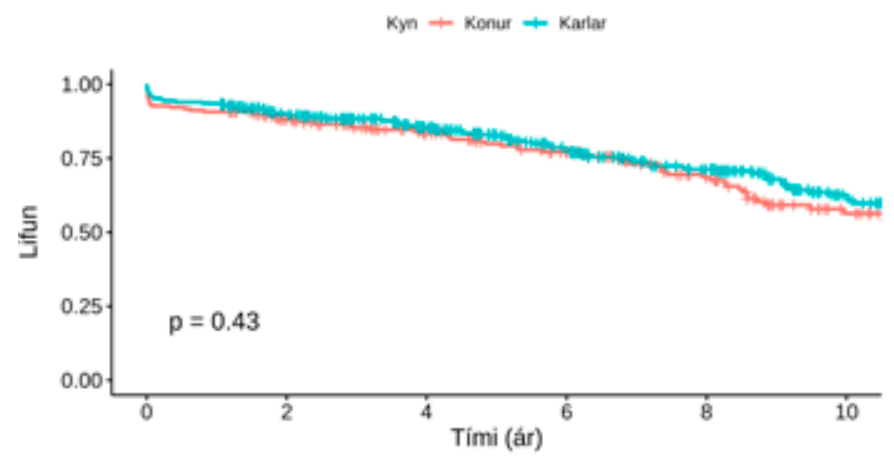

Fjöldi i hættu

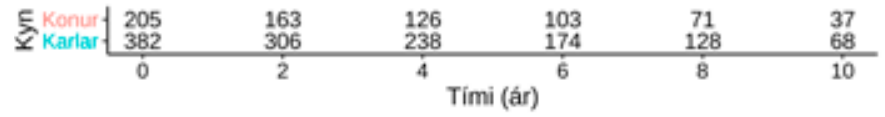

Mynd 1. Kaplan-Meier-graf sem sýnir heildarlifun sjúklinga eftir að̆gerð.

sýnt að konum sé síður vísað í hjartaaðgerðir sökum óljósra einkenna. ${ }^{32,33}$ Konur próa einnig síðar með sér kransæðasjúkdóm miðað við karla, ${ }^{34}$ sem endurspeglast í rannsókn okkar, en prátt fyrir hærri aldur gengust færri konur undir kransæðahjáveitu samtímis lokuskiptum. Af sömu ástæðu var EuroSCORE II kvenna fyrir aðgerð marktækt hærra, en karla en kvenkyn og aldur eru sjálfstæðir forspárpættir í pessu spálíkani. 19,20,35

Lokuflatarmál fyrir aðgerð var marktækt minna hjá konum fyrir aðgerð en sambærilegt pegar leiðrétt var fyrir heildar-líkamsyfirborði einstaklingsins. Hjartaómskoðun fyrir aðgerð sýndi hins vegar að konur voru með hærra prýstingsfall yfir lokuna. Petta bendir til alvarlegri ósæðarlokuprengsla hjá konum. Í flestum erlendum rannsóknum hafa konur sömuleiðis lengra genginn sjúkdóm og alvarlegri einkenni. ${ }^{20,36}$ Ekki sást pó munur á einkennum fyrir aðgerð hjá körlum og konum en hafa ber í huga að rannsóknin var aftursýn sem erfiðar mat á alvarleika einkenna en miðað við framskyggna rannsókn.

Ígræddar lokur voru sambærilegar fyrir bæði kyn en í 83,6\% tilfella var notast við lífrænar lokur og voru $57 \%$ peirra án grindar. Eins og búast mátti við fengu konur marktækt minni lokur en karlar, enda ósæðarrót peirra minni. Tangar- og vélartími reyndist sambærilegur milli kynja prátt fyrir hærra hlutfall kransæðahjáveitu hjá körlum. Petta gæti skýrst af prengri ósæðarrót kvenna sem oft gerir lokuskiptin tæknilega erfiðari.

Tíðni alvarlegra fylgikvilla var sambærileg milli kynja og sama átti við um minniháttar fylgikvilla. Pó höfðu konur hærri tíðni pvagfærasýkinga, enda eru pær almennt næmari fyrir pvagfærasýkingum. ${ }^{37}$ Konur fengu einnig fleiri einingar af rauðkornapykkni í legunni prátt fyrir að blæða marktækt minna í brjóstholskera en karlar. Almennt eru konur með lægri blóðrauða fyrir aðgerð en karlar og virðist sem blóðgjöf sé oft ákveðin út frá blóðrauðagildi sem ekki tekur tillit til pessa mismunar, en rannsóknir hafa sýnt að tíðni blóðgjafa hjá konum er yfirleitt hærri en hjá körlum eftir aðgerðir. ${ }^{38}$ Tíðni heilablóðfalls innan 30 daga frá aðgerð reyndist lægri hér (1,6\%) en í erlendum rannsóknum (um 2,5\%). ${ }^{23}$ Tíðni nýtilkomins gáttatifs reyndist hins vegar hærri, bæði fyrir karla og konur, eða í kringum 63\% (á móti um 42\% erlendis). ${ }^{39}$ Hárri tíðni gáttatifs eftir opnar hjartaaðgerðir á Íslandi hefur áður verið lýst og er skýringin ekki pekkt. ${ }^{40}$ Sama á við um tíðni enduraðgerða vegna blæðinga sem reynist mun hærri hér á landi $(14,5 \%)$ en í erlendum rannsóknum (2-3\%). ${ }^{41,42}$ Loks lágu konur lengur inni á spítala en karlar en ekki var pó munur á legutíma á gjörgæsludeild eftir aðgerð. Huganlega getur pessi munur að einhverju leyti skýrst af hærri aldri, en sennilega koma pó fleiri pættir við sögu, enda aldursmunurinn aðeins tvö ár.

Fjölpáttaaðhvarfsgreining leiddi í ljós að kvenkyn reyndist ekki forspárpáttur 30 daga dánartíðni eftir að leiðrétt hafði verið fyrir helstu áhættupáttum hjarta- og æðasjúkdóma, aldri og EuroSCORE II. Pá reyndist kvenkyn ekki heldur forspárpáttur í flóknara fjölpáttalíkani sem gert var til næmisgreiningar. Niðurstöður okkar eru sambærilegar sumum erlendum rannsóknum ${ }^{1,720,43}$ en pó ekki öllum. Sumar peirra sýna kvenkyn sem sjálfstæðan forspárpátt hærri 30 daga dánartíðni. ${ }^{18,22,36}$ Í pessu sambandi ber pó að hafa í huga að hugsanlega var rannsóknarpýðið of lítið til að sýna fram á marktækan mun á 30 daga dánartíðni (hætta á tölfræðilegri villu af gerð 2).

Pótt rannsóknin hafi ekki beinst að langtímaárangri var reiknuð langtímalifun fyrir bæði kyn og reyndist hún sambærileg fyrir konur og karla. Lifunartölur okkar eru í stórum dráttum sambærilegar við rannsókn frá árinu $2010^{36}$ og fyrri rannsóknir af Landspítala. ${ }^{26,44}$

Styrkleiki pessarar rannsóknar er að hún nær til alla sjúklinga heillar pjóðar sem gengust undir fyrstu ósæðarlokuskipti sín vegna prengsla, og spannar 12 ár. Notaðar voru tvær aðskildar skrár til að finna sjúklingahópinn sem minnkar líkur á pví að einhverjir sjúklingar hafi ekki verið teknir með í rannsóknina. Helsti veikleiki rannsóknarinnar er að hún er afturskyggn og upplýsingar fyrir aðgerð, svo sem áhættupættir og einkenni, eru ekki eins nákvæmar og ef hún hefði verið framskyggn. Rannsóknarpýðið var heldur ekki nægilega stórt til að bera saman sjaldgæfa fylgikvilla og hugsanlegt að fyrir einhverja peirra sæist marktækur munur ef sjúklingahópurinn hefði verið stærri.

Niðurstöður pessarar rannsóknar sýna að konur eru rúmur priðjungur peirra sem gangast undir opin ósæðarlokuskipti á Íslandi. Pær eru eldri en karlar pegar kemur að aðgerð og virðast vera með alvarlegri lokusjúkdóm. Engu að síður er heildartíðni snemmkominna fylgikvilla sambærileg fyrir bæði kyn, sem og 30 daga dánartíðni og langtímalifun. Kvenkyn reyndist ekki sjálfstæður forspárpáttur fyrir dauða innan 30 daga frá aðgerð.

\section{Pakkir}

Við pökkum Gunnhildi Jóhannsdóttur, skrifstofustjóra á skurðsviði Landspítala, fyrir hjálp við gagnaöflun. 


\section{Heimildir}

1. Iung B, Baron G, Tornos P, Gohlke-Barwolf C, Butchart EG, Vahanian A. Valvular heart disease in the community: a European experience. Curr Probl Cardiol 2007; 32: 60961.

2. De Sciscio P, Brubert J, De Sciscio M, Serrani M, Stasiak J, Moggridge GD. Quantifying the Shift Toward Transcatheter Aortic Valve Replacement in LowRisk Patients: A Meta-Analysis. Circ Cardiovasc Qual Outcomes 2017; 10.

3. Braverman AC, Guven H, Beardslee MA, Makan M, Kates AM, Moon MR. The bicuspid aortic valve. Curr Probl Cardiol 2005; 30: 470-522.

4. Carabello BA, Paulus WJ. Aortic stenosis. Lancet 2009; 373: 956-66.

5. Faggiano P, Aurigemma GP, Rusconi C, Gaasch WH Progression of valvular aortic stenosis in adults: literature review and clinical implications. Am Heart J 1996; 132 (2 Pt 1): 408-17.

6. Ross J, Jr., Braunwald E. Aortic stenosis. Circulation 1968; 38 (1 Suppl): 61-7.

7. Kelly TA, Rothbart RM, Cooper CM, Kaiser DL, Smucker ML, Gibson RS. Comparison of outcome of asymptomatic to symptomatic patients older than 20 years of age with valvular aortic stenosis. Am J Cardiol 1988; 61: 123-30.

8. Zhao Y, Nicoll R, He YH, Henein MY. The effect of statins on valve function and calcification in aortic stenosis: A meta-analysis. Atherosclerosis 2016; 246: 318-24.

9. Emery RW EA, Knutsen A, Raikar GV. Aortic Valve Replacement with a Mechanical Cardiac Valve Prosthesis. 3 ed. Cohn LH, editor. The McGraw-Hill Company, New York 2008.

10. Arnórsson $\mathrm{P}$ TB, Ólafsson G, Alfreðsson H, Jóhannsson $\mathrm{KB}$, Guðbjartsson T. Hjartaskurðlækningar á Íslandi í 20 ár. Læknablaðið 2007; 4: 320.

11. Cribier A, Eltchaninoff $\mathrm{H}$, Bash A, Borenstein N, Tron $\mathrm{C}$ Bauer F, et al. Percutaneous transcatheter implantation of an aortic valve prosthesis for calcific aortic stenosis: first human case description. Circulation 2002; 106: 3006-8.

12. Smith CR, Leon MB, Mack MJ, Miller DC, Moses JW, Svensson LG, et al. Transcatheter versus surgical aortic-valve replacement in high-risk patients. N Engl J Med 2011; 364: 2187-98.

13. Eggebrecht $\mathrm{H}$, Mehta RH. Transcatheter aortic valve implantation (TAVI) in Germany 2008-2014: on its way to standard therapy for aortic valve stenosis in the elderly? EuroIntervention 2016; 11: 1029-33.

14. Reardon MJ, Van Mieghem NM, Popma JJ, Kleiman NS, Sondergaard L, Mumtaz M, et al. Surgical or Transcatheter Aortic-Valve Replacement in Intermediate-Risk Patients. N Engl J Med 2017; 376: 1321-31.

15. Leon MB, Smith CR, Mack MJ, Makkar RR, Svensson LG, Kodali SK, et al. Transcatheter or Surgical Aortic-Valve Replacement in Intermediate-Risk Patients. N Engl J Med 2016; 374: 1609-20.

16. Zhou Y, Wang Y, Wu Y, Zhu J. Transcatheter versus surgical aortic valve replacement in low to intermediate risk patients: A meta-analysis of randomized and observational studies. Int J Cardiol 2017; 228: 723-8.
17. Roedler S, Neuhauser J, Sodeck G, Dziodzio T, Juraszek A, Zimpfer $\mathrm{D}$, et al. Gender-related differences in patients undergoing mechanical aortic valve replacement with the CarboMedics valve. J Cardiovasc Surg (Torino) 2011; 52: 887-94.

18. Saxena A, Poh CL, Dinh DT, Reid CM, Smith JA, Shardey $\mathrm{GC}$, et al. Does patient gender affect outcomes after concomitant coronary artery bypass graft and aortic valve replacement? An Australian Society of Cardiac and Thoracic Surgeons Database study. Cardiology 2011; 119: 116-23.

19. Heinze G, Christ T, Leonards CO, Dohmen PM, Konertz W. Risk and Outcome of Aortic Valve Surgery in the Transcatheter Valve Era: The Gender Aspect. Ann Thorac Cardiovasc Surg 2015; 21: 446-51.

20. Elhmidi Y, Piazza N, Mazzitelli D, Wottke M, Lange R, Bleiziffer S. Sex-related differences in 2197 patients undergoing isolated surgical aortic valve replacement. J Card Surg 2014; 29: 772-8.

21. Chaker Z, Badhwar V, Alqahtani F, Aljohani S, Zack CJ Holmes DR, et al. Sex Differences in the Utilization and Outcomes of Surgical Aortic Valve Replacement for Severe Aortic Stenosis. J Am Heart Assoc 2017; 6 .

22. Duncan AI, Lin J, Koch CG, Gillinov AM, Xu M, Starr NJ. The impact of gender on in-hospital mortality and morbidity after isolated aortic valve replacement. Anesth Analg 2006; 103: 800-8

23. Stamou SC, Robich M, Wolf RE, Lovett A, Normand SL, Sellke FW. Effects of gender and ethnicity on outcomes after aortic valve replacement. J Thorac Cardiovasc Surg 2012; 144: 486-92.

24. Aranki SF, Rizzo RJ, Couper GS, Adams DH, Collins JJ, Jr., Gildea JS, et al. Aortic valve replacement in the elderly. Effect of gender and coronary artery disease on operative mortality. Circulation 1993; 88 (5 Pt 2): II17-23.

25. Helgason D, Helgadottir S, Viktorsson SA, Orrason AW, Ingvarsdottir IL, Geirsson A, et al. Acute kidney injury and outcome following aortic valve replacement for aortic stenosis. Interact Cardiovasc Thorac Surg 2016; 23: 266-72.

26. Ingvarsdóttir IL, Viktorsson SA, Hreinsson K, Sigurðsson MI, Helgadóttir S, Arnórsson P, et al. Lokuskipti vegna ósæðarlokuprengsla á Íslandi 2002-2006: Ábendingar og snemmkomnir fylgikvillar. Læknablaðið 2011; 97: 523-7.

27. Viktorsson SA, Ingvarsdóttir IL, Hreinsson K, Sigurðsson MI, Helgadóttir S, Arnórsson P, et al. Lokuskipti vegna ósæðarlokuprengsla á Íslandi 2002-2006: Langtímafylgikvillar og lifun. Læknablaðið 2011; 97: 591-5.

28. Fisher JD. New York Heart Association Classification. Arch Intern Med 1972; 129: 836.

29. Smith ER. The angina grading system of the Canadian Cardiovascular Society. Can J Cardiol 2002; 18: 439, 42

30. Nashef SA, Roques F, Sharples LD, Nilsson J, Smith C, Goldstone AR, et al. EuroSCORE II. Eur J Cardiothorac Surg 2012; 41: 734-44; discussion 44-5.

31. Bellomo R, Ronco C, Kellum JA, Mehta RL, Palevsky P, Acute Dialysis Quality Initiative w. Acute renal failure - definition, outcome measures, animal models, fluid therapy and information technology needs: the Second International Consensus Conference of the Acute Dialysis Quality Initiative (ADQI) Group. Crit Care 2004; 8: R20412.
32. Hartzell M, Malhotra R, Yared K, Rosenfield HR, Walker JD, Wood MJ. Effect of gender on treatment and outcomes in severe aortic stenosis. Am J Cardiol 2011; 107: 1681-6.

33. Bach DS. Prevalence and characteristics of unoperated patients with severe aortic stenosis. J Heart Valve Dis 2011; 20: 284-91.

34. Maas AH, Appelman YE. Gender differences in coronary heart disease. Neth Heart J 2010; 18: 598-602.

35. Berndt R, Panholzer B, Huenges K, Jussli-Melchers J, Schoeneich F, Friedrich C, et al. Impact of Gender on Outcome in Octogenarians after Coronary Artery Bypass Grafting. Thorac Cardiovasc Surg 2017; 65: 286-91.

36. Fuchs C, Mascherbauer J, Rosenhek R, Pernicka E, Klaar $\mathrm{U}$, Scholten C, et al. Gender differences in clinical presentation and surgical outcome of aortic stenosis. Heart 2010; 96: 539-45.

37. Minardi D, d'Anzeo G, Cantoro D, Conti A, Muzzonigro G. Urinary tract infections in women: etiology and treatment options. Int J Gen Med 2011; 4: 333-43.

38. Oddason KE, Guðbjartsson T, Guðmundsson S, Kárason S, Hreinsson K, Sigurðsson GH. Má bæta notkun blóðhluta á gjörgæsludeildum? Samanburður við klínískar leiðbeiningar. Læknablaðið 2014; 100: 11-7.

39. Swinkels BM, de Mol BA, Kelder JC, Vermeulen FE, Ten Berg JM. New-onset postoperative atrial fibrillation after aortic valve replacement: Effect on long-term survival. J Thorac Cardiovasc Surg 2017; 154: 492-8.

40. Helgadottir S1, Sigurdsson MI, Ingvarsdottir IL, Arnar DO, Gudbjartsson T. Atrial fibrillation following cardiac surgery: risk analysis and long-term survival. J Cardiothorac Surg. 2012; 7: 87.

41. Vivacqua A, Koch CG, Yousuf AM, Nowicki ER, Houghtaling PL, Blackstone EH, et al. Morbidity of bleeding after cardiac surgery: is it blood transfusion, reoperation for bleeding, or both? Ann Thorac Surg 2011; 91: $1780-90$.

42. Colson PH, Gaudard P, Fellahi JL, Bertet H, Faucanie M, Amour J, et al. Active Bleeding after Cardiac Surgery: A Prospective Observational Multicenter Study. PLoS One 2016; 11: e0162396

43. Onorati F, D’Errigo P, Barbanti M, Rosato S, Covello RD, Maraschini A, et al. Different impact of sex on baseline characteristics and major periprocedural outcomes of transcatheter and surgical aortic valve interventions: Results of the multicenter Italian OBSERVANT Registry. J Thorac Cardiovasc Surg 2014; 147: 1529-39.

44. Sigurðsson MI, Helgadóttir S, Ingvarsdóttir IL, Viktorsson SA, Hreinsson K, Arnórsson P, et al. Árangur kransæðahjáveituaðgerða og ósæðarlokuskipta hjá öldruðum. Læknablaðið 2012; 98: 11-6. 


\section{Early outcome of surgical aortic valve replacement for aortic stenosis in Icelandic females}

\author{
Anna Guơlaug Gunnarsdóttir \\ Kristján Orri Víðisson' \\ Sindri Aron Viktorsson ${ }^{2}$ \\ Árni Johnsen ${ }^{1}$ \\ Daði Helgason ${ }^{3}$ \\ Inga Lára Ingvarsdóttir \\ Sólveig Helgadóttir ${ }^{5}$ \\ Arnar Geirsson ${ }^{6}$ \\ Tómas Guðbjartsson ${ }^{1,2}$
}

Introduction: Aortic valve replacement (AVR) for aortic stenosis (AS) is the second most common open-heart procedure performed in Iceland. The aim of this study was to analyze the early outcome of AVR among females in Iceland.

Materials and methods: This was a retrospective study including 428 patients who underwent surgical AVR due to AS in Iceland from 2002-2013. Information was gathered from medical records, including pre- and postoperative results of echocardiography and complications. Overall survival was estimated (Kaplan-Meier) and logistic regression used to identify predictors of operative mortality. The median follow-up time was 8.8 years (0-16.5 years).

Results: Of the 428 patients, 151 were female (35.3\%), that were on average 2 years older than men $(72.6 \pm 9.4$ vs. $70.4 \pm 9.8$ yrs., $\mathrm{p}=0.020$ ). Preoperative symptoms were similar, but women had significantly higher EurosSCORE II than men ( $5.2 \pm 8.8$ vs. $3.2 \pm$ 4.6, $p=0.002$ ). Maximal pressure-gradient across the aortic valve was higher for women $(74.4 \pm 29.3 \mathrm{mmHg}$ vs. $68.0 \pm 23.4 \mathrm{mmHg}$ $\mathrm{p}=0,013)$ but postoperative complications, operative mortality $(8.6 \%$ vs. $4.0 \%, p=0.068)$ and 5 -year survival $(78.6 \%$ vs. $83.1 \%, p=0.245)$ were comparable for women and men. Logistic regression analysis showed that female gender was not an independent predictor of 30-day mortality (OR $1.54,95 \% \mathrm{Cl} 0.63-3.77$ ).

Conclusions: Females constitute one third of patients that undergo AVR for AS in Iceland. At the time of surgery females are two years older than men and appear to have a more significant aortic stenosis at the time of surgery. However, complication rates, operative mortality and long-term survival were comparable for both genders.

${ }^{1}$ Faculty of Medicine, University of Iceland, Departments of ${ }^{2}$ Cardiothoracic Surgery, and ${ }^{3}$ Internal Medicine, Landspitali University Hospital, Departments of Anesthesia and Intensive Care Unit, ${ }^{4}$ Sahlgrenska University Hospital, Gothenburg, Sweden, ${ }^{5}$ Akademiska University Hospital, Uppsala, Sweden, ${ }^{6}$ Department of Cardiac Surgery, Yale University Hospital, New Haven.

Key words: aortic stenosis, aortic valve replacement, females, outcome, complications, survival.

Correspondence: Tómas Guðbjartsson tomasgudbjartsson@hotmail.com 